\title{
Enhancing supply chain performance through supply chain practices
}

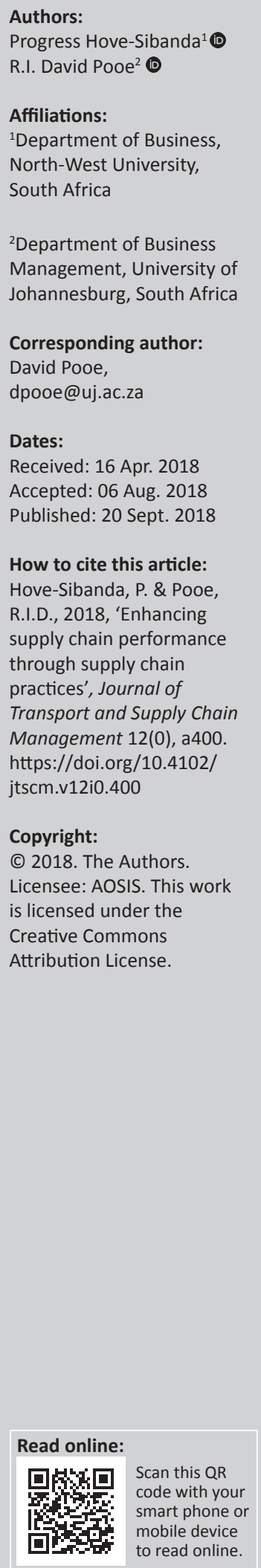

Background: The recognised relationship between company performance and supply chain performance has prompted managers, practitioners and researchers alike to seek a better understanding of the performance of supply chains. To this end, many firms have adopted and implemented various supply chain practices and enhanced collaboration and more recently e-collaboration within supply chains.

Objectives: The aim of this study was to investigate how firms can enhance their supply chain performance through supply chain practices and supply chain e-collaboration.

Method: A quantitative design was adopted in which a survey questionnaire was administered to a sample of 500 senior managers representing some 350 firms. A non-probability sampling employing convenience and purposive methods was used. A confirmatory factor analysis and structural equation modelling technique were undertaken to assess the psychometric properties of the measurement scale and to test hypotheses using the path modelling technique.

Results: The key findings of this study were as follows: Supply chain practice was found to have a strong positive and significant relationship with supply chain e-collaboration, while supply chain e-collaboration has a strong positive and significant influence on strategic information sharing. Strategic information sharing has a positive and significant influence on supply chain competence and supply chain performance. Supply chain e-collaboration has a positive and significant influence on supply chain competence, while supply chain competence was found to have a negative and insignificant influence on supply chain performance.

Conclusion: This study concludes that firms can use supply chain practices to enhance their supply chain e-collaboration and supply chain performance. The study also provides a useful framework for analysing the relationship between supply chain practices, supply chain e-collaboration, strategic information sharing, supply chain competence and supply chain performance.

\section{Introduction and background}

In modern times, firms have come to appreciate that supply chains have become a critical source of competition, such that increasingly there is recognition that real competition is no longer between companies but between supply chains (Botes, Niemann \& Kotzé 2017:143; Roussel 2013:301). This recognised relationship between company performance and supply chain performance has prompted managers, practitioners and researchers alike to seek a better understanding of the performance of supply chains. Some authors have gone to the point of suggesting that organisational success largely depends upon the performance of the supply chains in which the firm functions as a partner (Hoejmosel, Roehrich \& Grosvold 2014:82; Vermeulen, Nieman \& Kotze 2016:6). In this regard, Taghipour et al. (2015:144) posit that improvement in the overall supply chain performance can lead to improvements in the overall company performance. This is because improved supply chain performance has been associated with the improvement of the overall business efficiencies (Sodhi, Son \& Tang 2012; Alexiev, Volberda \& Van den Bosch 2016). In recognising the increasing importance of the role of supply chains, firms have over the years sought to work on their supply chain practices, the nature and degree of collaboration with suppliers, the nature and extent of information sharing and the overall supply chain competence.

The quest to improve supply chain performance has seen firms in various industries worldwide adopt and implement different forms of supply chain management (SCM) practices (Li 2014:1). Regarding SCM practices, Da Silva, Neto and Pires (2012:10) posit that SCM practices incorporate cooperation and training as well as support in the development of products, processes, purchases and delivery systems with a firm's suppliers. Mayaka (2015:19) defines supply chain practices as a set of activities undertaken in an organisation to promote effective management of its supply 
chain while Van der Vaart and Van Donk (2008:47) define them as tangible activities or technologies that play a primary role in the collaboration among the focal firm, its suppliers and customers. The current study focuses on the intrafirm and interfirm supply chain practices that influence supply chain performance. The intrafirm supply chain practices investigated include supply chain planning, just-in-time (JIT) production and inventory systems and delivery practice, while interfirm supply chain practices include supply chain e-collaboration, strategic information sharing and supply chain competence.

Enhancing collaboration and more recently e-collaboration between buying firms and suppliers has been seen as one of the primary ways to improve supply chain performance (Kang \& Moon 2016:307-316). A few empirical studies have been conducted in various contexts to seek to determine the relationship between e-collaboration and supply chain performance (De Mattos 2011:1-21; Rosenzweig 2009:462478). However, little remains known about supply chain e-collaboration, particularly as a mediator for the relationship between intrafirm supply chain practices and strategic information sharing, supply chain competence and supply chain performance.

Supply chain competence has also been associated with a better performing supply chain (Derwick \& Hellström 2017:200-218). Firms need to nurture and protect their core competencies in order to capture all the benefits that a firm can derive from them. More importantly, these core competencies are the essential ingredients of the relationships that unleash the unique and inimitable value-creating abilities of a supply chain known as 'supply chain competencies'. Such supply chain competences might include the ability to effectively manage inventory, accurately forecast customer demands and fill their orders, produce quality products and design low pollution production along with delivery processes (Lysons \& Farrington 2012:339).

Previous studies have revealed that many supply chain partnering firms are hesitant to share strategic information (Chu \& Lee 2006:1570; Prajogo \& Olhager 2012:516). Understandably, the practice of strategic information sharing regularly involves risks and costs. As a result, firms tend to resort to information hoarding and opportunistic behaviour among supply chain partners (Nogues 2014:27). According to Dittmann (2013:48), information hoarding results in supply chain partners being reluctant or unwilling to share their firm's strategic information; this often occurs when a partner, after receiving information from the other supply chain partner, uses that information to the disadvantage of the disclosing partner. Yet information hoarding can result in a bad reputation and declining profitability. Thus supply chain partners need to guard against information hoarding behaviour among themselves (Dittmann 2013:48). Previous studies have linked information sharing to an improved supply chain or supplier performance (Inderfurth, Sadrieh \& Voigt 2012:40-425; Pooe, Mafini \& Louwry-Okoumba 2015:1-11).
According to the Council for Scientific and Industrial Research Report (2014:16) there is a major gap between the knowledge of SCM and the successful implementation of supply chain collaboration strategies within South African organisations. In this regard, Barloworld Logistics (2015:49) observed that for firms to improve their supply chains and their potential for future returns, they need to improve their supply chain collaboration, among other things. Furthermore, Barloworld Logistics (2015:61) reported that only 29\% of South African firms are fully utilising supply chain collaboration strategies, while $46 \%$ are partly collaborating and $14 \%$ have plans to implement supply chain collaboration strategies. This clearly shows that there is a lot to be done in terms of SCM implementation in South Africa with regards to collaboration and information sharing.

Over the past decade (2005-2015), SCM research has advanced and extended to include a range of perspectives such as supplier relationships, supply chain network structure and collaboration (Breite \& Koskinen 2014; Lejeune \& Yakova 2005; Narasimhan et al. 2008; Sandberg 2007). While some studies have explored the antecedents of supply chain performance, much still needs to be explored and understood about this concept. The existing literature on supply chain performance has largely focused on developed countries such as Australia (Jie, Parton \& Cox 2007), Germany (Wagner \& Bode 2008), Taiwan (Liu 2009) and the United States (US) (Fawcett et al. 2007). With the exception of some developing countries such as Turkey and Bangladesh, one rarely comes across studies on supply chain performance that focused on developing countries (Rashed, Azeem \& Halim 2010; Sezen 2008). South Africa is no exception in this regard.

Furthermore, while the relevant studies have investigated various antecedents of supply chain performance, none of these studies have combined intrafirm supply chain practice with the interfirm practices of supply chain e-collaboration, strategic information sharing and supply chain competence as its antecedents. For instance, Sezen (2008) investigated the relationship between design, integration information sharing and supply chain performance. Fawcett et al. (2009) examined the impact of information sharing on supply chain performance using semi-structured interviews.

Studies that examined the effects and impact of supply chain practices on performance only focused on interfirm supply chain practice (Chow et al. 2008; Sukati et al. 2012). Rarely can one find studies that examined the influence of intrafirm supply chain practices on supply chain performance, with the interfirm practices as mediators. Although Zhou and Benton (2007) focused on intrafirm supply chain practice, these were linked to SCM and not to supply chain performance through theinterfirm practices of supply chain e-collaboration, strategic information sharing and supply chain competence. The absence of such a link between supply chain practice and supply chain performance through the interfirm practices of e-collaboration, strategic information sharing and supply chain competence makes this study significant in filling such 
a research gap. This study, therefore, focused on the entire range of supply chains in South African firms, where less has been done in terms of research. Hence, the aim of the study was to investigate how firms can enhance their supply chain performance through supply chain practices and supply chain e-collaboration. The remainder of this article is organised as follows: Firstly, the theoretical framework underpinning the study is discussed, followed by the presentation of the conceptual framework and hypothesis development. Next, the article explains the research methodology employed, followed by a report of the study's empirical findings. Finally, the article concludes with the recommendations and directions for future research.

\section{Theoretical underpinning}

This study employed the relational view and the learning and knowledge perspective theories as the lens through which the influence of supply chain practice on supply chain e-collaboration, strategic information sharing, supply chain competence and supply chain performance was investigated.

\section{Relational view theory}

The relational view is a theory developed by Dyer and Singh in 1998 after Asanuma (1989) found that the relation-specific skills developed between Japanese suppliers and their automakers generated surplus profits and competitive advantages for collaborating firms. The relational view theory has its foundations in the market and resource-based views that have significantly and substantially contributed to the initial understanding of the sources of a firm's competitive advantage where firms compete on an individual basis (Dyer \& Singh 1998:660). Thus the market and resource-based views were found inadequate in explaining the sources of differential performance and competitive advantages in alliances or networks (Dyer \& Singh 1998:660; Lavie 2006:639).

According to Wong (2011:35) the market and resource-based views seem to have overlooked the fact that the advantages (or disadvantages) of an individual firm are often linked to the advantages (or disadvantages) of a network of relationships in which the firm is embedded. It is from such deficiencies in literature that the notion of the relational view is founded, to supplement and complement the two theories on firms' competitive advantage. The theory holds that the relationship between firms or a dyad of firms is an increasingly important unit of analysis for understanding firms' differential performance (relational rents) and competitive advantage. Hence this theory is relevant in shedding light on resources resulting from collaboration, information and practices within the context of a supply chain as opposed to an individual company. The relational theory is applicable in this study because the present study argues the role and value of supply chain practices, which, although developed within the firm, can go a long way in improving the effectiveness of the supply chains, thereby standing to benefit other firms within the network. Further, the study argues that focus on the collaborative aspects within the supply chain will likely improve the supply chain performance.

\section{The learning and knowledge perspective theory}

The development of the learning and knowledge perspective theory can be linked with the works of Kogut (1988) and Hamel (1991). The theory postulates that supply chain partners establish network or alliance relationships to exploit opportunities that reveal knowledge creation and organisational learning (Cao 2007:21). Verwaal and Hesselmans (2004:444) in support argue that firms can strengthen their competitive advantage through knowledge creation and organisational learning. Hence, the theory views collaboration in supply chains as an effective means of transferring knowledge and new technical skills across firms (Cao 2007:17), mainly because collaboration in supply chains provides a conducive environment for learning (Verwaal \& Hesselmans 2004:445) and enhances partner-enabled knowledge creation in markets (Malhotra, Gasains \& El-Sawy 2005:22).

The argument is that collaboration in supply chains facilitates the sharing of tacit knowledge among supply chain member firms, and it might be difficult for individual firms to find and buy such knowledge in the market because of its tacit nature. This implies that firms can only access the tacit knowledge of other firms through relationships such as collaborations in supply chains, which creates an advantage only to the collaborating partners. In this study, the learning and knowledge perspective theory was used to explain the influence of supply chain e-collaboration on strategic sharing of information about the unique as well as tacit capabilities accruing to the supply chain member firms, which usually are not available for sale in the markets. This theory was also instrumental in explaining the notion of supply chain competence.

\section{Conceptual framework and hypothesis development Conceptual framework}

The research conceptual framework in this study conceptually portrays the research variables as shown in Figure 1. The framework shows the hypothesised links between supply chain practice, supply chain e-collaboration, strategic information sharing, supply chain competence and supply chain performance. In the conceptual framework depicted in Figure 1, supply chain practice is the predictor variable, while supply chain e-collaboration, strategic information sharing and supply chain competence are the mediating variables. Supply chain performance is the outcome variable for this study. The links posited between the research variables are

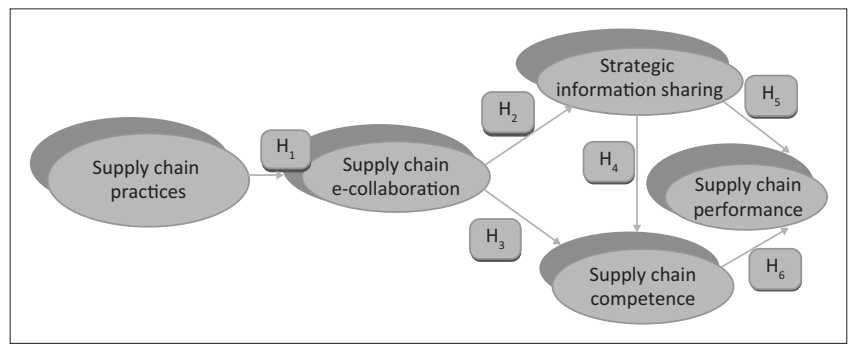

FIGURE 1: The research conceptual framework. $\mathrm{H}$, hypothesis. 
depicted in Figure 1 as hypotheses (i.e. $\mathrm{H}_{1}, \mathrm{H}_{2}, \mathrm{H}_{3}, \mathrm{H}_{4}, \mathrm{H}_{5}$ and $\mathrm{H}_{6}$ ) and are further presented in the next section.

In light of the literature reviewed, the theoretical bases presented and the conceptual framework developed, the following hypotheses are developed.

\section{Supply chain practice and supply chain e-collaboration}

A study by Lambert and Cooper (2000) investigated the influence of supply chain practice on supply chain e-collaboration. The authors recommended that firms in a supply chain network need to understand their positions in the supply chain and identify their primary supply chain members before investing in any supply chain practices that may lead to links that facilitate partnerships and collaborations. Zhou and Benton (2007) linked supply chain practice to supply chain dynamism and information sharing as an effect or outcome variable and found that information sharing causes firms to implement supply chain practices such as the supply chain planning, JIT production and delivery under different supply chain dynamics. For instance, sharing important information with customers and suppliers enables a firm to properly forecast the demand and supply customer needs just in time. It also helps the firm to use production methods that minimises waste, as well as delivery methods that reduce costs (Mbanje \& Lunga 2015:162). As a result of increasing global competition, companies are forced to employ supply chain practices such as the JIT inventory system, which largely ensures low cost, high quality and reliable products, thereby enhancing firm competitiveness and performance (Shukla, Garg \& Agarwal 2011:2061). In their study, Day and Lichtenstein (2007:317) found that SCM practices have an impact on firm performance, especially when aligned to the business unit strategy. Hence, this study hypothesises the following:

$\mathbf{H}_{\mathbf{1}}$ : Supply chain practice has a positive influence on supply chain e-collaboration

\section{Supply chain e-collaboration and strategic information sharing}

The need for e-collaboration has sprouted in SCM as a technology-enabled systems approach that integrates and synchronises a supply chain and has seen many firms invest in information technology (IT) resources to improve supply chain performance (Samadi \& Kassou 2015:493). Insofar as collaboration is concerned, Jayaram and Tan (2010:262) hold that the role of effective supply chain e-collaboration remains important in the current global landscape, mainly because of the trends of outsourcing and the value-added functions associated with external functions. Some previous studies have found that e-collaboration among supply chain members facilitates information sharing (Choi \& Ko 2012:557) and improves individual firm performance, as well as creating a sustainable competitive advantage (Cao \& Zhang 2010:172; Ho 2013:8). Hence, this study postulates the following:

$\mathbf{H}_{2}$ : Supply chain e-collaboration has a positive influence on strategic information sharing.

\section{Supply chain e-collaboration and supply chain competence}

Supply chain e-collaboration not only influences the sharing of strategic information among the collaborating firms, but it also creates a competence for the entire supply chain (Breite \& Koskinen 2014:11). Rosenzweig (2009:471) reveals that the benefits of e-collaboration in supply chains cause greater improvements to smaller firms than larger ones. The rationale was that the larger the firm, the more hindrance there will be for them to effectively use technology to improve customer service in spite of their relatively larger resource base and bargaining power. Noteworthy is the argument advanced by Ma (2008:68) that without good understanding and preparation, e-collaboration can also damage business to the supply chain member firms. This is because e-collaboration may encourage unequal resource commitment among supply chain partners, which in turn will create a dependency syndrome from the lesser contributors and ultimately yield inefficiencies. In light of this, the present study posits the following:

$\mathbf{H}_{3}$ : Supply chain e-collaboration has a positive influence on supply chain competence.

\section{Strategic information sharing and supply chain competence}

Information sharing has been defined by Shou et al. (2013:2) as the extent to which a firm openly communicates important and sensitive information to its partners. Previous studies have revealed that many supply chain partnering firms are hesitant to share strategic information (Chu \& Lee 2006:1570; Prajogo \& Olhager 2012:516). This is quite common, especially where the risk and cost of sharing strategic information is solely a burden of the disclosing supply chain partner. More so, this is also common where there is no mechanism defined prior to allocating some of the resultant additional profit as well as risks and costs to the disclosing supply chain partner (Chu \& Lee 2006:1570). A study by Rashed et al. (2010) examined the combined effect of information and knowledge sharing on a supplier's operational performance in supplier-buyer relationships of Bangladesh. That said, the present study advances the following hypothesis:

$\mathbf{H}_{4}$ : Strategic information sharing has a positive influence on supply chain competence.

\section{Strategic information sharing and supply chain performance}

A study by Rashed et al. (2010) examined the combined effect of information and knowledge sharing on a supplier's operational performance in supplier-buyer relationships of Bangladesh. Their study found that information sharing with key suppliers does not affect the supplier's operational performance. In addition, the findings revealed that knowledge sharing with key suppliers has a weaker positive effect on the supplier's operational performance. A few studies have found that effective information sharing and supply chain practice are important factors in achieving good 
supply chain performance and that information sharing may bring a significant amount of advantages such as inventory reduction and efficient inventory management, cost reduction, increasing visibility (significant reduction of uncertainties), significant reduction or complete elimination of the bullwhip effect, improved resource utilisation and improved organisational efficiency (Lotfi et al. 2013:298-304; Zhou \& Benton 2007). Strategic information sharing with suppliers occurs when the focal firm shares essential and strategic information of the firm with its key suppliers. Hence, the following hypothesis is postulated:

$\mathbf{H}_{5}$ : Strategic information sharing has a positive influence on supply chain performance.

\section{Supply chain competence and supply chain performance}

De Wit and Meyer (2010:113) define a competence as an intangible resource that shows the fitness of a firm to perform in a particular field. In other words, a firm is said to have a competence if it has knowledge, capabilities and the attitude required to successfully operate in a specific area. Collective learning is the source of competitive advantage for the entire supply chain and it stems from the communication, involvement and a deep commitment of the supply chain partners working across their firms' boundaries (De Wit \& Meyer 2010:357). Such learning is facilitated by a supply chain as a system that forms learning entities and transforms itself through the collective learning of all its individual supply chain partners (Breite \& Koskinen 2014:11). The idea is that a supply chain learns from its individual supply chain collaborating firms through their sharing and transferring of an individual firm's core competencies such as tacit knowledge.

Chow et al. (2008) examined the associations between supply chain components (supply chain practices, concerns and competences) and organisational performance in the US and Taiwan. The study found that supply chain competencies have positive effects on organisational performance in both the US and Taiwan and that supply chain practices and competencies are significantly associated in both the US and Taiwan. This will in turn improve the supply chain activities, thereby improving the performance of the entire supply chain of those collaborating firms. Yet Derwick and Hellström (2017:216) concluded that, although competence in SCM is a key to business success, the subject is ambiguous and an explicit need exists for more research. Hence, the following hypothesis is made:

$\mathbf{H}_{6}$ : Supply chain competence has a positive influence on supply chain performance.

\section{Research methodology}

The present study adopted a quantitative approach to help establish the statistical evidence on the strengths of influence of supply chain practice on supply chain e-collaboration, strategic information sharing, supply chain competence and supply chain performance. Quantitative research follows a scientific method, usually descriptive in nature, and helps the researcher determine causal relationships between variables; the data can be interpreted using statistical analysis (Berndt \& Petzer 2011:348). This study employed a descriptive analysis because the underlying relationships of variables surrounding the problem are known (Cant et al. 2003:33).

Firms whose senior managers are affiliated to the association of supply chain management professionals in Africa (SAPICS) comprised the target population of this study. SAPICS is a professional membership-based association that aims to advance individuals and organisations in the supply chain profession. The senior managers ranged from demand planners, purchasing managers, procurement managers, logistics engineers, logistics managers and supply chain managers to owners or managers of small and medium enterprises. The study employed a non-probability sampling method involving convenience and purposive sampling (Kumar, Aaker \& Day 2002:306) - convenience in that the questionnaires were distributed to the senior managers attending the SAPICS conference, which happens to be the biggest gathering for supply chain practitioners from all kinds of industries, and purposive in that the respondent had to be a supply chain practitioner who had a deep knowledge of his or her firm and the industry. Therefore, questionnaires were distributed on a one-respondent-one-firm basis. The questionnaires were distributed to a sample size of 500 supply chain members representing some 350 firms attending an annual SAPICS conference (01-03 June 2014) in Sun City, South Africa. Following the data collection process, a total of 280 usable questionnaires was collected.

\section{Measuring instrument and operationalisation}

The questionnaire in this study was developed primarily on the basis of instruments used in other studies. These include Zhou and Benton (2007:1358) for supply chain practice; Hosseini, Azizi and Sheikhi (2012:86-87) for supply chain e-collaboration; Kocoglu et al. (2011:1639) for strategic information sharing; Chow et al. (2008:677) for supply chain competence; and Kocoglu et al. (2011:1639) for supply chain performance. All the measurement items were measured on a five-point Likert-type scale that used 1 (strongly disagree) to 5 (strongly agree) to express the degree of agreement or 1 (not implemented) to 5 (extensively implemented). For a detailed definition of research measures used in this study, see Tables $1-5$.

\section{Data analysis}

Data gathered for the purposes of this study were analysed using a confirmatory factor analysis (CFA) and structural equation modelling (SEM). This study performed a CFA to establish the factor model fit - in other words, to test whether the sample data fit or supported the hypothesised research factor model. Various precautions were taken during the study to ascertain the validity and reliability of the sample data gathered. The item-to-total correlation values were used to measure the reliability of multi-item construct measures in this study. Construct validity was measured using both convergent 
TABLE 1: Sample profile.

\begin{tabular}{|c|c|c|c|}
\hline Characteristic & Description & $n$ & $\%$ \\
\hline \multirow{5}{*}{$\begin{array}{l}\text { Size of the firm by number } \\
\text { of employees }\end{array}$} & 5 or less & 20 & 7.1 \\
\hline & $6-10$ & 15 & 5.4 \\
\hline & $11-20$ & 12 & 4.3 \\
\hline & $21-50$ & 28 & 10.0 \\
\hline & 51 or above & 205 & 73.2 \\
\hline Total & & 280 & 100.0 \\
\hline \multirow[t]{5}{*}{ Turnover } & Less than R1 million & 3 & 1.1 \\
\hline & $\mathrm{R} 1 \mathrm{~m}-\mathrm{R} 5 \mathrm{~m}$ & 29 & 10.4 \\
\hline & $\mathrm{R} 5.1 \mathrm{~m}-\mathrm{R} 10 \mathrm{~m}$ & 19 & 6.8 \\
\hline & $\mathrm{R} 10.1 \mathrm{~m}-\mathrm{R} 20 \mathrm{~m}$ & 25 & 8.9 \\
\hline & Above $\mathrm{R} 20 \mathrm{~m}$ & 204 & 72.9 \\
\hline Total & & 280 & 100.0 \\
\hline \multirow[t]{5}{*}{ Firm age } & 2 years or less & 20 & 7.1 \\
\hline & $3-5$ years & 3 & 1.1 \\
\hline & $6-10$ years & 33 & 11.8 \\
\hline & $11-20$ years & 48 & 17.1 \\
\hline & 21 years or above & 176 & 62.9 \\
\hline Total & & 280 & 100.0 \\
\hline \multirow[t]{9}{*}{ Sector } & Manufacturing & 120 & 42.9 \\
\hline & Retailing & 36 & 12.9 \\
\hline & Construction & 5 & 1.8 \\
\hline & Mining & 19 & 6.8 \\
\hline & Tourism & 4 & 1.4 \\
\hline & Agriculture & 14 & 5.0 \\
\hline & Financial & 6 & 2.1 \\
\hline & Logistics & 73 & 26.1 \\
\hline & Marketing & 3 & 1.1 \\
\hline Total & & 280 & 100.0 \\
\hline
\end{tabular}

and discriminant validity. According to Cooper and Schindler (2011:281), convergent validity is concerned with the degree to which the measurement items show homogeneity within the same latent variable measured. Discriminant validity is established when, based on theory, two or more latent variables are predicted to be uncorrelated, and the scores obtained by measuring them are indeed empirically found to be so (Sekaran \& Bougie 2009:160). Using Amos 21, the model fit indices tested in CFA to assess the factor model fit included the chisquare or degrees of freedom, goodness of fit index (GFI), augmented goodness of fit index (AGFI), normed fit index (NFI), incremental fit index (IFI), Tucker-Lewis index (TLI), composite fit index (CFI), root-mean-square residual (RMR) and root-mean-square error of approximation (RMSEA).

\section{Research findings}

Table 1 shows that $73.2 \%$ of the surveyed firms employed more than 51 employees, while 10\% employed between 21 and 50 employees. Only $4.3 \%$ of the sample employed between 11 and 20 workers in their firms. Table 1 also depicts that $72.9 \%$ of the sample firms had a sales turnover of above R20 million, while $10.4 \%$ had a sales turnover of between $\mathrm{R} 1 \mathrm{~m}$ and $\mathrm{R} 5 \mathrm{~m}$. These results show that most (72.9\%) of the sample firms in this study were large firms. Moreover, $62.9 \%$ of the firms were aged 21 and above, while $17.1 \%$ of the firms were aged between 11 and 20, suggesting that the majority of the respondents were well-established companies. Finally, $42.9 \%$ of the sample firms were in the manufacturing sector, $26.1 \%$ in logistics, $12.9 \%$ in retailing, $6.8 \%$ in mining, $5 \%$ in agriculture, $2.1 \%$ in financial services, $1.8 \%$ in construction, $1.4 \%$ in tourism and $1.1 \%$ in marketing services.

As shown in Table 2, the item-to-total values ranged from 0.42 to 0.75 for supply chain practice; 0.36 to 0.73 for supply chain e-collaboration; 0.39 to 0.75 for strategic information sharing; 0.39 to 0.75 for supply chain competence and 0.35 to 0.74 for supply chain performance. All the measurement items for the five latent variables had item-to-total values greater than the acceptable threshold value of 0.3 or above (often $\leqq 0.3$ ) (Dunn, Seaker \& Waller 1994:145). Table 2 also reveals that the Cronbach's alpha coefficients were between 0.87 and 0.92 for all five latent research variables. Thus, all the Cronbach's alpha values for all the research variables used in this study were above the acceptable threshold value of 0.7 used in the study of Nunnally and Bernstein (1994:24). Overall, the measurement items used in this study were highly reliable because all the item-to-total values were above the recommended value of 3 and all the Cronbach's alpha coefficients were closer to 1 . The study further used composite reliability checks as shown in Table 2 to complement the item-to-total correlations and the Cronbach's coefficient alpha values.

As indicated in Table 3, all the intercorrelation values for all paired latent variables are less than 1.00. They all range between 0.70 and 0.95 , thus confirming the existence of discriminant validity. However, because the correlation value of supply chain e-collaboration and strategic information sharing is above 0.70 (in particular 0.90) and very close to 1.00, this necessitated other tests for discriminant validity (Nunnally \& Bernstein 1994:12). Therefore, further tests (particularly the average variance extracted shared variance [AVE-SV] test and the average variance extracted [AVE] values of less than 1) were performed to establish discriminant validity. As Table 3 shows, all the AVE values range from 0.45 to 0.51 and are all far below 1, which confirms the existence of discriminant validity. More so, Table 3 indicates that the highest shared variance values of all the variables are between 0.32 and 0.40. All these figures are less than the AVE values (ranging from 0.45 to 0.51 ) of their respective latent variables, thereby further confirming that the measures of all five different variables were indeed distinct and heterogeneous (Fornell \& Larcker 1992:40). Table 4 shows the results of the CFA measurement model fit.

Table 4 indicates that the measurement model yielded a ratio of chi-square value to degree of freedom of 3.69. The recommended threshold range is between 1 and 3 . Although the current study has a value of above 3, the difference of 0.69 is still tolerable. According to Reisinger and Mavondo (2005:221), chi-square to degree of freedom values below 5 still provide a good model fit. As such, the chi-square to degree of freedom value of 3.69 in this study is marginally accepted and reflects a good model fit. Table 4 also shows GFI, AGFI, NFI, relative fit index (RFI), IFI, CFI and TLI values $(0.95,0.90,0.94,0.91,0.96,0.96$ and 
TABLE 2: Accuracy analysis statistics: Reliability tests.

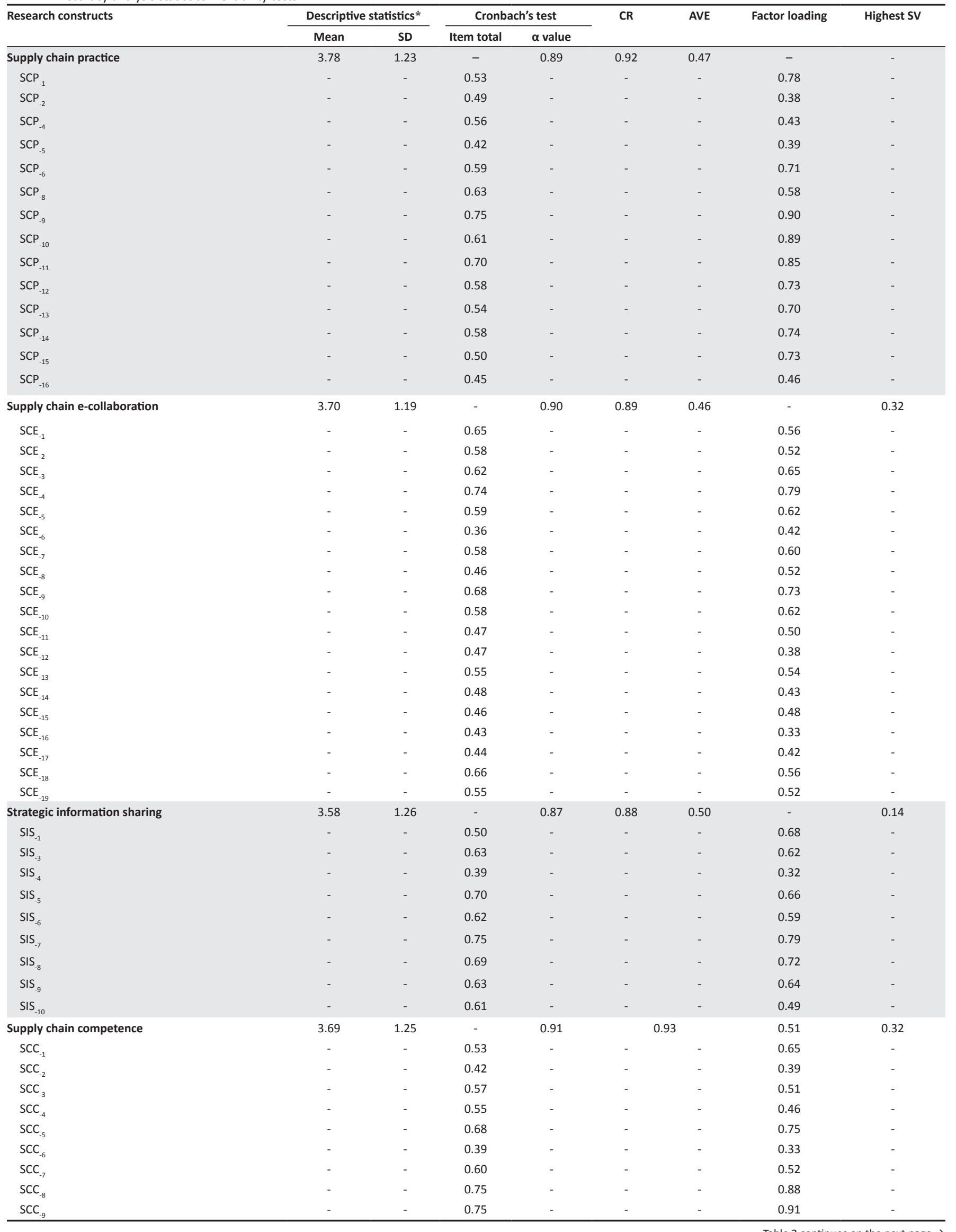


TABLE 2 (Continues): Accuracy analysis statistics: Reliability tests.

\begin{tabular}{|c|c|c|c|c|c|c|c|c|}
\hline \multirow[t]{2}{*}{ Research constructs } & \multicolumn{2}{|c|}{ Descriptive statistics* } & \multicolumn{2}{|c|}{ Cronbach's test } & \multirow[t]{2}{*}{ CR } & \multirow[t]{2}{*}{ AVE } & \multirow[t]{2}{*}{ Factor loading } & \multirow[t]{2}{*}{ Highest SV } \\
\hline & Mean & SD & Item total & $\alpha$ value & & & & \\
\hline $\mathrm{SCC}_{-10}$ & - & - & 0.69 & - & - & - & 0.85 & - \\
\hline $\mathrm{SCC}_{-11}$ & - & - & 0.75 & - & - & - & 0.89 & - \\
\hline $\mathrm{SCC}_{-12}$ & - & - & 0.71 & - & - & - & 0.87 & - \\
\hline $\mathrm{SCC}_{-13}$ & - & - & 0.71 & - & - & - & 0.66 & - \\
\hline $\mathrm{SCC}_{-14}$ & - & - & 0.65 & - & - & - & 0.81 & - \\
\hline Supply chain performance & 3.66 & 1.27 & - & 0.92 & 0.93 & 0.45 & - & 0.39 \\
\hline $\mathrm{CP}_{-1}$ & - & - & 0.57 & - & - & - & 0.61 & - \\
\hline $\mathrm{CP}_{-2}$ & - & - & 0.68 & - & - & - & 0.76 & - \\
\hline $\mathrm{CP}_{-3}$ & - & - & 0.66 & - & - & - & 0.69 & - \\
\hline $\mathrm{CP}_{-4}$ & - & - & 0.64 & - & - & - & 0.67 & - \\
\hline $\mathrm{CP}_{-5}$ & - & - & 0.72 & - & - & - & 0.79 & - \\
\hline $\mathrm{CP}_{-6}$ & - & - & 0.62 & - & - & - & 0.65 & - \\
\hline $\mathrm{CP}_{-7}$ & - & - & 0.35 & - & - & - & 0.46 & - \\
\hline $\mathrm{CP}_{-9}$ & - & - & 0.58 & - & - & - & 0.63 & - \\
\hline $\mathrm{CP}_{-10}$ & - & - & 0.74 & - & - & - & 0.83 & - \\
\hline $\mathrm{CP}_{-11}$ & - & - & 0.68 & - & - & - & 0.76 & - \\
\hline $\mathrm{CP}_{-12}$ & - & - & 0.52 & - & - & - & 0.63 & - \\
\hline $\mathrm{CP}_{-13}$ & - & - & 0.47 & - & - & - & 0.53 & - \\
\hline $\mathrm{CP}_{-14}$ & - & - & 0.45 & - & - & - & 0.46 & - \\
\hline $\mathrm{CP}_{-15}$ & - & - & 0.63 & - & - & - & 0.68 & - \\
\hline $\mathrm{CP}_{-16}$ & - & - & 0.72 & - & - & - & 0.77 & - \\
\hline $\mathrm{CP}_{-17}$ & - & - & 0.63 & - & - & - & 0.70 & - \\
\hline
\end{tabular}

SCP, supply chain performance; SCE, supply chain e-collaboration; SIS, strategic information sharing; SCC, supply chain competence; $C P$, supply chain performance; SV, shared variance; CR, composite reliability; AVE, average variance extracted.

TABLE 3: Correlations matrix.

\begin{tabular}{lccccc}
\hline Research variables & CP & SCP & SCE & SIS & SCC \\
\hline CP & 1.000 & - & - & - & - \\
SCP & 0.728 & 1.000 & - & - & - \\
SCE & 0.908 & 0.769 & 1.000 & - & - \\
SIS & 0.851 & 0.711 & 0.902 & 1.000 & - \\
SCC & 0.701 & 0.945 & 0.762 & 0.730 & 1.000 \\
\hline
\end{tabular}

$\mathrm{CP}$, supply chain performance; SCP, supply chain practice; SCE, supply chain e-collaboration; SIS, strategic information sharing; SCC, supply chain competence.

TABLE 4: Confirmatory factor analysis - model fit index results.

\begin{tabular}{lc}
\hline Fit index & Result \\
\hline Chi-square/df & 3.69 \\
Goodness of fit index & 0.95 \\
Adjusted goodness of fit index & 0.90 \\
Root-mean-square residual & 0.06 \\
Comparative fit index & 0.96 \\
Root-mean-square error of approximation & 0.09 \\
Normal fit index & 0.94 \\
Tucker-Lewis index & 0.93 \\
Incremental fit index & 0.96 \\
Relative fit index & 0.91 \\
\hline
\end{tabular}

TABLE 5: Structural equation modelling - model fit index results.

\begin{tabular}{lc}
\hline Fit index & Result \\
\hline Chi-square/df & 148.340 \\
Goodness of fit index & 0.998 \\
Adjusted goodness of fit index & 0.977 \\
Root-mean-square residual & 0.003 \\
Comparative fit index & 1.000 \\
Root-mean-square error of approximation & 0.018 \\
Normal fit index & 0.999 \\
Tucker-Lewis index & 1.000 \\
Incremental fit index & 1.000 \\
Relative fit index & 0.994 \\
\hline
\end{tabular}

0.93, respectively) that are above the recommended threshold of 0.9 or above, thereby further reflecting a good model fit.

Table 4 further reports RMR value of 0.06 and is less than 0.08 ; thus it yields a reasonable model fit. The table also shows a RMSEA value of 0.09. Although this figure is above the range of between 0.05 and 0.08 , which yields a reasonable fit, the value is still within the tolerable range of 0.09 or less. Based on the model fit acceptability guidelines and the actual CFA model fit results in Table 4, all ten selected model fit indices provide an acceptable overall fitness of the measurement model to the specified sample data. The next section provides a discussion of the structural model, starting with the SEM model fit to the hypotheses testing.

Table 5 further shows the GFI, AGFI, NFI, RFI, IFI, CFI and TLI values $(0.998,0.977,0.999,0.994,1.000,1.000$ and 1.000, respectively) that are above the recommended threshold of 0.9 or above. These results further confirm that the estimated model fits the sample data in this study well, which provides a good model fit. Table 5 also reports an RMR of 0.003 , which is within the recommended threshold of less than 0.05 , thus yielding a very good model fit. The table also depicts a RMSEA value of 0.018 and is closer to zero, which provides a very good model fit. Based on the model fit acceptability guidelines and the actual SEM model fit results in Table 5, all ten selected model fit indices provide an good overall fitness of the SEM model to the specified sample data. The next section provides a discussion of the structural model (hypotheses testing). 


\section{Structural equation modelling hypotheses testing results}

Figure 2 shows the results of the SEM hypothesis tests.

Table 6 presents a summary of the SEM hypotheses results.

Figure 2 and Table 6 show the six hypothesised linear relationships between supply chain practice and supply chain e-collaboration $\left(\mathrm{H}_{1}\right)$; supply chain e-collaboration and strategic information sharing $\left(\mathrm{H}_{2}\right)$; supply chain e-collaboration and supply chain competence $\left(\mathrm{H}_{3}\right)$; strategic information sharing and supply chain competence $\left(\mathrm{H}_{4}\right)$; strategic information sharing and supply chain performance $\left(\mathrm{H}_{5}\right)$; and supply chain competence and supply chain performance $\left(\mathrm{H}_{6}\right)$. Of these six posited linear relationships, five $\left(\mathrm{H}_{1}, \mathrm{H}_{2}, \mathrm{H}_{3}, \mathrm{H}_{4}\right.$ and $\left.\mathrm{H}_{5}\right)$ were validated because they all had positive path coefficients and $p$-values less than 0.001 as well as $t$-values above the recommended value of $2.00 . \mathrm{H}_{6}$ was the only hypothesis that was not supported and validated, as it had a negative path coefficient significantly closer to zero and a $p$-value greater than 0.1 along with a $t$-value of less than -2.00 . However, regression analysis was also performed to avoid making wrong conclusions, especially on the claims of $\mathrm{H}_{6}$.

\section{$\mathrm{H}_{1}$ : Supply chain practice has a positive influence on supply chain e-collaboration in South Africa}

A linear relationship (positive and significant) was hypothesised between supply chain practice and supply chain e-collaboration. This hypothesis was formulated from the objective that aimed to investigate the influence of supply chain practice on supply chain e-collaboration. As shown in Table 6, supply chain practice was found to have a strong positive and significant linear relationship with supply chain

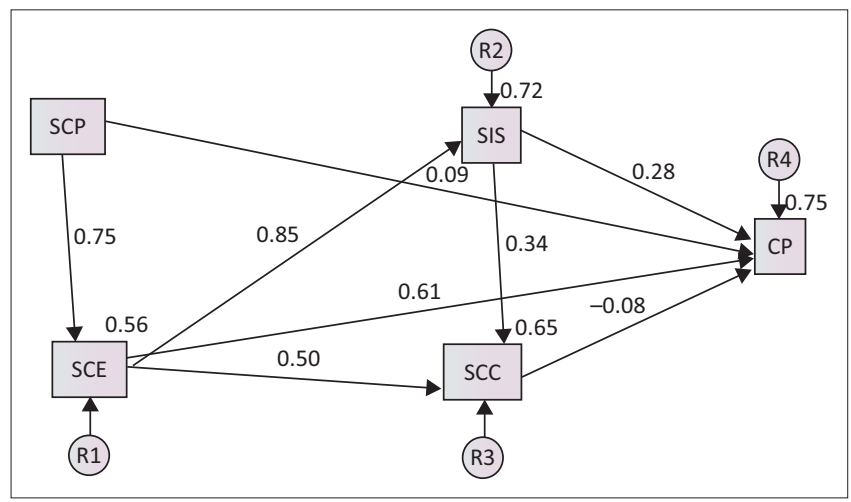

FIGURE 2: Structural equation modelling hypotheses testing results.

SCP, supply chain practice; SCE, supply chain e-collaboration; SIS, strategic information sharing; SCC, supply chain competence; $C P$, supply chain performance; $R$, residual term. e-collaboration. A high and positive path coefficient (0.75) validates the hypothesised strong positive influence that supply chain practice has on supply chain e-collaboration. A hypothesised path coefficient of above 0.5 indicates a positive influence (Hair et al. 2006:79). As such, the high and positive path coefficient along with the high levels of significance shown by both the critical value of 20.002 and a $p$-value of less than 0 validates and renders validity and support to $H_{1}$. These findings further confirm the relational view theory, which postulates that critical resources of a firm may extend beyond the firm boundaries and may be embedded in interfirm resources as well as routines (Dyer \& Singh 1998). The resources (i.e. site, human and physical specificity) and routines are an outcome of the supply chain practices employed by the supply chain member firms.

Through the support and validation of $\mathrm{H}_{1}$, the study highlights the need for firms to first identify who their key partners are, know their position in the supply chain, the length of the supply chain and the type of supply chain practices they implement, before they can invest in e-collaboration commitments with the supply chain partners. The results of the study suggest that supply chain e-collaboration encourages the sharing and transfer of important knowledge among partners in a supply chain. In other words, supply chain member firms who understand their position in the supply chain have identified their key supply chain partners and committed themselves to e-collaboration relationships with these key supply chain partners, placing themselves in a position in which they can enjoy the benefits of sharing and transferring important and strategic tacit information, which their rivals who are not in such relationships would not be able to find in the secondary markets.

\section{$\mathrm{H}_{2}$ : Supply chain e-collaboration has a positive influence on strategic information sharing}

A positive and significant influence of supply chain e-collaboration on strategic information sharing was posited. Table 6 indicates that supply chain e-collaboration has a strong positive (path coefficient of 0.85 ) and highly significant ( $C^{* * *}-p$-value less than $0.001 ; t$-value of 28.365) influence on strategic information sharing. These findings suggest that the successful adoption of technology-enabled collaborations can enhance trust and commitment to share important information (e.g. tacit information on manufacturing and customers) among supply chain member firms. These findings are consistent with the previous work of Sheu, Yen and Chae (2006:40), which suggested high levels of trust and

TABLE 6: Summary of structural equation modelling hypotheses results.

\begin{tabular}{|c|c|c|c|c|c|c|c|}
\hline Variables & Path & Variables & Hypothesis & Path coefficient & SE & Critical region & $p$ \\
\hline Supply chain practice & $\rightarrow$ & Supply chain e-collaboration & $\mathrm{H}_{1}$ & 0.75 & 0.036 & 20.002 & $C^{*}$ \\
\hline Supply chain e-collaboration & $\rightarrow$ & Strategic information sharing & $\mathrm{H}_{2}$ & 0.85 & 0.036 & 28.365 & $\mathrm{C}^{*}$ \\
\hline Supply chain e-collaboration & $\rightarrow$ & Supply chain competence & $\mathrm{H}_{3}$ & 0.50 & 0.072 & 7.968 & $C^{*}$ \\
\hline Strategic information sharing & $\rightarrow$ & Supply chain competence & $\mathrm{H}_{4}$ & 0.34 & 0.059 & 5.387 & $\mathrm{C}^{*}$ \\
\hline Strategic information sharing & $\rightarrow$ & Supply chain performance & $\mathrm{H}_{5}$ & 0.28 & 0.052 & 5.069 & $\mathrm{C}^{*}$ \\
\hline Supply chain competence & $\rightarrow$ & Supply chain performance & $\mathrm{H}_{6}$ & -0.08 & 0.072 & -1.115 & $0.265 * *$ \\
\hline
\end{tabular}

$*, p<0.001$ (significance level); $* *, p>0.1$ (significance level). 
interdependence as the pushing factors of managers to engage a firm in further collaborations (e.g. supply chain collaboration) and the sharing of information. Therefore, this study strongly validates and supports the claim made by $\mathrm{H}_{2}$ that supply chain e-collaboration has a positive influence on strategic information sharing.

\section{$\mathrm{H}_{3}$ : Supply chain e-collaboration has a positive influence on supply chain competence}

The present study also posited a significant and positive influence of supply chain e-collaboration on supply chain competence. As shown in Figure 2 and Table 6, supply chain e-collaboration has a positive (path coefficient of 0.50 ) and significant $\left(\mathrm{C}^{* * * *}\right.$ or $p$-value less than $0.001 ; t$-value of 7.968$)$ influence on supply chain competence. The positive path coefficient of exactly 0.5 confirms the existence of a reasonable positive effect of supply chain e-collaboration in creating supply chain competences. These findings suggest that supply chain member firms that invest in and use e-collaboration tools such as the message-based, shared collaborative as well as the electronic procurement and marketplace systems for their buying and selling with each other are able to learn collectively and create a supply chain competence. These results support the relational view theory assertion, which claims that the investment in complementary resources and interorganisational assets by supply chain partners can generate relational rents (Dyer \& Singh 1998). Therefore, this study validates and supports the hypothesis that supply chain e-collaboration has a positive influence on supply chain competence $\left(\mathrm{H}_{3}\right)$.

\section{$\mathrm{H}_{4}$ : Strategic information sharing has a positive influence on supply chain competence}

The study also hypothesised a positive influence of strategic information sharing on supply chain competence as stated in $\mathrm{H}_{4}$ above. Figure 2 and Table 6 indicate that strategic information sharing has a weak positive (path coefficient of $0.34)$ and significant $\left(C^{* * *}\right.$ or $p$-value less than $0.001 ; t$-value of 5.387) influence on supply chain competence. The influence is said to be weak because the path coefficient of 0.34 is less than the recommended threshold value of 0.5 . These findings suggest that although the sharing of strategic information among supply chain partners can enhance their ability to learn collectively and develop a supply chain competence, there are other factors besides strategic information sharing that are key in the development of a supply chain competence. In other words, the sharing of strategic information among e-collaborating firms can enable firms to develop supply chain competences with the help of other factors. These results seem to confirm those of Liu and Kumar (2003:525), who suggested that a centralised e-hub as an information sharing platform enhances the ability of firms to accurately forecast customer demand, promptly fulfil customer orders and even produce quality products (supply chain competences). The findings also corroborate the results from the work of Choi and Ko (2012:557), which found that e-collaboration can facilitate information sharing among partners. Because the influence is positive, though weak, and highly significant, the claims of $\mathrm{H}_{4}$ are validated in this study.
Therefore, this study validates and supports the claim that strategic information sharing has a positive influence on supply chain competence $\left(\mathrm{H}_{4}\right)$.

\section{$\mathrm{H}_{5}$ : Strategic information sharing has a positive influence on supply chain performance}

Strategic information sharing was posited to have a positive influence on supply chain performance in this study. The path diagram presented in Figure 2 and Table 6 show that strategic information sharing has a weak positive (path coefficient of 0.28 ) and significant (C*** or $p$-value less than 0.001 ; $t$-value of 5.069) influence on supply chain performance. The positive path coefficient of 0.28 is less than the acceptable threshold value of 0.5 , thereby suggesting a weak influence. More so, the positive path coefficient, though weak, indicates that strategic information sharing needs to complement other factors such as supply chain learning and competitive advantage to enhance the performance of the entire supply chain. In other words, if the sharing of information does not result in collective learning of the entire supply chain, such that a supply chain competitive edge is developed, information sharing makes a minor contribution in terms of supply chain performance.

The weaker path coefficient $(0.28)$ could be indicative of the fact that although the supply chain member firms in South Africa have some e-collaboration tools that allow them to share strategic information, they do not use them to collaborate with their supply chain partners. It could also be that the firms are partly collaborating with their partners such that the e-collaboration tools are not fully utilised to effectively share important information and improve their supply chain performance. This is consistent with the work of Rossouw and Binnekade (2013:4), who found that $46 \%$ of the participating South African firms never or rarely collaborated with their supply chain partners, while $46 \%$ were partially managing to successfully collaborate. This forced the firms who did not collaborate to forfeit the benefits of using the e-collaboration tools to improve their firm and supply chain performance through sharing of tacit and important information. For the partly collaborating firms, it becomes difficult for the other supply chain partners to trust and commit their resources fully, when working with partly committed partners. In the end, the improvement made in terms of supply chain performance will be almost insignificant (weak). The results of this study are also consistent with the empirical evidence from Sezen (2008) and Kocoglu et al. (2011), which found a positive relationship between information sharing and supply chain performance. Therefore, this study validates and supports the hypothesis that strategic information sharing has a positive influence on supply chain performance $\left(\mathrm{H}_{5}\right)$.

\section{$\mathrm{H}_{6}$ : Supply chain competence has a positive influence on supply chain performance}

Finally, the study posited that supply chain competence has a positive influence on supply chain performance. As noted from Figure 2 and Table 6, supply chain competence has a weak negative (path coefficient of -0.08) and not significant 
( $p$-value greater than $0.1 ; t$-value of -1.115 ) influence on supply chain performance. These results seem to be inconsistent with the two theories used in this study (both the relational view and learning and knowledge perspective) and the previous empirical evidence. To further clarify and mitigate the effects of the data analysis methods used, a regression analysis was performed. This was done with an aim of further ascertaining the influence of supply chain competence on supply chain performance. Given the negative path coefficient significantly closer to zero with no significance, this study fails to validate and support the claims of $\mathrm{H}_{6}$. Therefore, this study invalidates and renders no support for $\mathrm{H}_{6}$.

The generally received wisdom is that a supply chain competence should improve the supply chain performance through collective learning, which provides the supply chain a competitive edge against rivals working as individual firms. This study reports a negative influence, which means supply chain competence development constrains the performance of a supply chain. This is likely to be common where the collaborating partners in a supply chain are not fully committed because of lack of or insufficient incentives, which do not tally with their roles in the supply chain. In such cases, partners are hesitant or even unwilling to share their information because there is no reward for doing so.

\section{Conclusion, contributions and directions for further research}

The current study sought to investigate how firms can enhance their supply chain performance through supply chain practices and supply chain e-collaboration. The article reviewed literature on the empirical constructs of the study, namely supply chain performance, chain practices, supply chain e-collaboration, strategic information sharing and supply chain competence. The theoretical grounding of the study, underpinned by the relational view and learning and knowledge perspective theories, was explained. Based on the reviewed literature, the article articulated the problem, determined the research gap, posited a conceptual framework and accordingly postulated six hypothesis statements. The study established that collaborating firms implement supply chain practices to enhance their supply chain e-collaborations with each other and enhance the sharing of strategic information with each other. The study also established that as these firms develop supply chain e-collaboration relationships and share strategic information, they also improve their supply chain competence through collective learning. Lastly, the study established that collaborating firms indirectly improve their supply chain performance by sharing strategic information with each other.

The study demonstrated that the ability of firms to effectively and fully share their strategic and important information can improve the performance of a firm as well as of the entire supply chain. For instance, as noted earlier, a supply chain plan is part of the important information that needs to be shared among collaborating supply chain partners. This is because it contains information that will guide all collaborative supply chain processes in order to optimise the entire supply chain and improve supply chain performance. The findings suggest that strategic information sharing has an indirect influence on supply chain performance. Thus, it requires other determinants of supply chain performance such as supply chain e-collaboration, supply chain practice, trust and balanced bargaining power to strongly improve supply chain performance.

This study makes two sets of contributions to the existing body of knowledge in the area of supply chain performance. The first set of contributions is theoretical in nature while the second set is managerial and policy-related in nature. By demonstrating a positive and significant relationship between supply chain practices (typically internal to the firm) and supply chain collaboration, the study validated the relational view theory, which postulates that critical resources of a firm may extend beyond the firm boundaries and may be embedded in interfirm resources. Managerially, the study demonstrates the need for firms to effectively implement the supply chain practices of supply chain planning, JIT production and inventory systems, as well as delivery practice, as this will lead to the improvement of their e-collaboration. This is necessary because supply chain practices play a major role in reducing the supply chain risks and costs through standardising supply chain processes. This standardisation will help firms better manage the information shared, which in turn develops a supply chain competence.

It is also important for firms to review and adopt the advanced collaboration technologies to keep abreast with their key supply chain partners as well as with competition. The type of technologies that these firms invest in can hinder their ability to capture benefits from using advanced information sharing structures. At a policy level, enhancing supply chain performance through e-collaboration means that government should ensure that the information and communication technology (ICT) costs are not so high as to deter small firms from investing in chain e-collaboration technologies. Regulation of the ICT industry and ensuring competition are some of the measures that policymakers may take in levelling the playing field, as it were, and creating a conducive environment for firms to use relevant technologies for collaboration and information sharing.

The invalidation of $\mathrm{H}_{6}$ suggests that future studies should investigate the nature and factors that collaborating firms need to adopt in order to improve their supply chain performance through supply chain competence. In other words, scholars can now try to investigate the possible factors linearly related with supply chain performance through supply chain competence. The results of this study also showed a weak positive influence of strategic information sharing on supply chain competence and performance. The implications suggested that it could be a question of the e-collaboration technologies used as well as the type of information sharing structures. Future studies can thus focus 
on the nature of e-collaboration technologies, the information sharing structures used and their influence on the quality and effectiveness of strategic information sharing.

While the empirical investigation succeeded in seeking answers to some of the interesting questions in the arena of supply chain practices, e-collaboration, strategic information sharing, supply chain competence and supply chain performance, it also has a few limitations. The collected data (from a single respondent per firm) may not be representative of the actual picture. Although empirical tests employing statistical tests to examine and ensure the absence of common method bias were used, these statistical tests are not without shortcomings. Hence future studies should attempt to gather perceptual responses from multiple respondents per firm. A second limitation is the fact that the findings of the study cannot really be generalised, owing to the fact that a non-probability sampling method was employed. Hence future studies should empirically test the proposed model more widely.

\section{Acknowledgements Competing interests}

The authors declare that they have no financial or personal relationships that may have inappropriately influenced them in writing this article.

\section{Authors' contributions}

The article is based on P.H.S.'s DTech dissertation, for which R.I.D.P. was the promoter. R.I.D.P. reviewed the manuscript for submission.

\section{Disclaimer}

The views expressed in this article are the authors' own and not an official position of the institution or funder.

\section{References}

Alexiev, A.S., Volberda, H.W. \& Van den Bosch, F.A.J., 2016, 'Interorganizational collaboration and firm innovativeness: Unpacking the role of the organizational environment', Journal of Business Research 69(2), 974-984.

Asanuma, B., 1989, 'Manufacturer-supplier relationships in Japan and the concept of relation-specific skill', Journal of the Japanese and International Economies 3(1), 1-30. https://doi.org/10.1016/0889-1583(89)90029-4

Barloworld Logistics, 2016, 'Embracing change for a sustainable future', Supply Chain Foresight Report, viewed 18 August 2018, from https://www.barloworld-logistics. com/wp-content/uploads/2017/04/supplychainforesight-2015-report.pdf

Berndt, A. \& Petzer, D., 2011, Marketing research, Pearson Education, Cape Town.

Botes, A., Niemann, W. \& Kotzé, T., 2017, 'Buyer-supplier collaboration and supply chain resilience: A case study in the petrochemical industry', South African Journal of Industrial Engineering 28(4), 183-199.

Breite, R. \& Koskinen, K.U., 2014, 'Supply chain as an auto poetic learning system' Supply Chain Management: An International Journal 19(1), 10-16. https://doi. org/10.1108/SCM-06-2013-0176

Cant, M., Gerber-Nel, C., Nel, D. \& Kotze, T., 2003, Marketing research, New Africa Books, Cape Town.

Cao, M., 2007, 'Achieving collaborative advantage through IOS-enabled supply chain collaboration: An empirical examination', Unpublished PhD dissertation, University of Toledo, $\mathrm{OH}$

Cao, M. \& Zhang, Q., 2010, 'The collaborative advantage: A firm's perspective', International Journal of Production Economics 128, 358-367. https://doi. org/10.1016/j.ijpe.2010.07.037

Choi, S. \& Ko, I., 2012, 'Leveraging electronic collaboration to promote organisational learning', International Journal of Information Management 32, 550-559. https:// doi.org/10.1016/j.ijinfomgt.2012.03.002
Chow, W.S., Madu, C.N., Kuei, C., Lu, M.H., Lin, C. \& Tseng, H., 2008, 'Supply chain management in the US and Taiwan: An empirical study', Omega 36(5), 665-679. https://doi.org/10.1016/j.omega.2006.01.001

Chu, W.H.J. \& Lee, C.C., 2006, 'Strategic information sharing in a supply chain', European Journal of Operations Research 174(3), 1567-1579. https://doi. org/10.1016/j.ejor.2005.02.053

Cooper, D.R. \& Schindler, P., 2011, Business research methods, McGraw-Hill, New York.

Da Silva, E.M., Neto, M.S. \& Pires, S.R.I., 2012, 'An evaluation of the variables and terminologies employed in the constructs of supply chain management practices' Journal of Operations and Supply Chain Management 5(1), 1-15. https://doi. org/10.12660/joscmv5n1p1-15

Day, M. \& Lichtenstein, S., 2007, 'Strategic supply management: The relationship between supply management practices, strategic orientation and their impact on organisational performance', Journal of Purchasing and Supply Management 12(6), 313-321. https://doi.org/10.1016/j.pursup.2007.01.005

De Mattos, C.A., 2011, 'E-collaboration technologies in the supply chain and its impact on the performance', POMS 23rd Annual Conference, Chicago, IL, April 20-23, 2011, pp. 1-21.

Derwick, P. \& Hellström, D., 2017, 'Competence in supply chain management: A systematic review', Supply Chain Management: An International Journal 22(2), 200-218. https://doi.org/10.1108/SCM-09-2016-0324

De Wit, B. \& Meyer, R., 2010, Strategy synthesis: Resolving strategy paradoxes to create competitive advantage, 2 nd edn., Cengage Learning, Canada.

Dittmann, J.P., 2013, Game-changing trends in supply chains, First Annual Report by Supply Chain Management, University of Tennessee, Knoxville, TN.

Dunn, S.C., Seaker, R.F. \& Waller, M.A., 1994, 'Latent variables in business logistics research: Scale development and validation', Journal of Business Logistics 15(2), 145-172.

Dyer, J.H. \& Singh, H., 1998, 'The relational view: Cooperative strategy and sources of inter-organisational competitive advantage', Academic Management Review 23(4), 660-679. https://doi.org/10.5465/amr.1998.1255632

Fawcett, S.E., Osterhaus, P., Magnan, G.M., Brau, J.C. \& McCarter, M.W., 2007 'Information sharing and supply chain performance: The role of connectivity and willingness', Supply Chain Management 12(5), 358-368. https://doi.org/ 10.1108/13598540710776935

Fawcett, S.E., Andraski, J.C., Fawcett, A.M. \& Magnan, G.M., 2009, 'The art of supply', Supply Chain Management Review, 18-25.

Fornell, C. \& Larcker, D., 1992, 'Structural equation models with unobservable variables and measurement error', Journal of Marketing Research 18(1), 39-50. https://doi.org/10.2307/3151312

Hair, J.F., Anderson, R.E., Tatham, R.L. \& Black, W.C., 2006, Multivariate data analysis, 6th edn., Prentice-Hall, London.

Hamel, G., 1991, 'Competition for competence and inter-partner learning within international strategic alliances', Strategic Management Journal 12(51), 83-104. https://doi.org/10.1002/smj.4250120908

Ho, H.D., 2008, 'Knowledge sharing and creation in supplier-supplier collaboration', Industrial Marketing Management, 1-14. https://doi.org/10.1016/j.indmarman. 2013.01.004

Hoejmosel, S.U., Roehrich, J.K. \& Grosvold, J., 2014, 'Is doing more doing better? The relationship between responsible supply chain management and corporate reputation', Industrial Marketing Management 43(1), 77-90. https://doi.org/ 10.1016/j.indmarman.2013.10.002

Hosseini, S.M., Azizi, S. \& Sheikhi, N., 2012, 'An investigation on the effect of supply chain integration on competitive capability: An empirical analysis of Iranian food industry', International Journal of Business and Management 7(5), 73-90.

Inderfurth, K., Sadrieh, A. \& Voigt, G., 2012, 'The impact of information sharing on supply chain performance under asymmetric information', Production and Operations Management 22(2), 410-425. https://doi.org/10.1111/j.19375956.2012.01372.x

Jayaram, J. \& Tan, K.C., 2010, 'Supply chain integration with third party logistics providers', International Journal of Production Economics 125, 262-271. https:// doi.org/10.1016/j.ijpe.2010.02.014

Jie, F., Parton, K. \& Cox, R., 2007, 'Supply chain practice, supply chain performance indicators and competitive advantage of Australian beef enterprises: A conceptual framework', paper read at the Australian Agricultural and Resource Economical Society (AARES), 51st Annual Conference, Queenstown, New Zealand, 13-16 February.

Kang, S. \& Moon, T., 2016, 'Supply chain integration and collaboration for improving supply chain performance: A dynamic capability theory perspective', 49th Hawail International Conference on System Sciences, Washington, DC, 05-08 January, pp. 307-316.

Kocoglu, I., Imamoglu, S.Z., Ince, H. \& Keskin, H., 2011, 'The effect of supply chain integration on information sharing: Enhancing the supply chain performance', Procedia Social and Behavioural Sciences 24, 1630-1649. https://doi. org/10.1016/j.sbspro.2011.09.016

Kogut, B., 1988, 'Joint ventures: Theoretical and empirical perspectives', Strategic Management Journal 9, 319-332. https://doi.org/10.1002/smj.4250090403

Kumar, V., Aaker, D.A. \& Day, G.S., 2002, Essentials of marketing research, 2nd edn., John Wiley \& Sons, New York.

Lambert, D.M. \& Cooper, M.A., 2000, 'Issues in supply chain management', Industrial Marketing Management 29(1), 1-6. https://doi.org/10.1016/S0019-8501(99) 00113-3 
Lavie, D., 2006, 'The competitive advantage of interconnected firms: An extension of the resource-based view' Academy of Management Review 31(3), 638-658. the resource-based view', Academy of Manag
https://doi.org/10.5465/amr.2006.21318922

Lejeune, M.A. \& Yakova, N., 2005, 'On characterizing the 4 c's in supply chain management', Journal of Operations Management 23(1), 81-100. https://doi. org/10.1016/j.jom.2004.09.004

Li, X., 2014, 'Operations management of logistics and supply chain: Issues and directions', Discrete Dynamics in Nature and Society 1, 1-7. https://doi. org/10.1155/2014/701938

Liu, C.H., 2009, 'The effect of a quality management system on supply chain performance: An empirical study in Taiwan', International Journal of Managemen 26(2), 285-294.

Liu, E.R. \& Kumar, A., 2003, 'Leveraging information sharing to increase supply chain configurability', paper read at the 24th International Conference on Information systems, Seattle, WA, 15-17 December, pp. 523-536.

Lotfi, Z., Mukhtar, M., Sahran, S. \& Zadeh, A.T., 2013, 'Information sharing in supply chain management', Proceedings of The 4th International Conference on Electrical Engineering and Informatics (ICEEI 2013), Selangor, Malaysia, 24-25 June, pp. 298-304.

Lysons, K. \& Farrington, B., 2012, Purchasing and supply chain management, 8th edn., Pearson Education, London.

Ma, C., 2009, 'E-collaboration: A universal key to solve fierce competition in tourism industry?', International Business Research 1(4), 65-71. https://doi.org/10.5539/ ibr.v1n4p65

Malhotra, A., Gasain, S. \& El-Sawy, O.A., 2005, 'Absorptive capacity configurations in supply chains: Gearing for partner-enabled market knowledge creation', MIS Quarterly 29(1), 145-187. https://doi.org/10.2307/25148671

Mayaka, R.L., 2015, 'Effect of supply chain management practices on performance of Barclays Bank of Kenya Limited', Master of Business Administration (Procurement \& Supply Chain Management) research project, University of Nairobi.

Mbanje, S. \& Lunga, J., 2015, Fundamental principles of supply chain management, Van Schaik, Pretoria.

Narasimhan, R., Kim, S.W. \& Tan, K.C., 2008, 'An empirical investigation of supply chain strategy typologies and relationships to performance', International Journal of Production Research 46(18), 5231-5259. https://doi.org/10.1080 Journal of Production

Nogues, G., 2014, 'The supply chain of the future', Illinois Institute of Technology special project, Spring 2014, Chicago, IL.

Nunnally, J.C. \& Bernstein, I., 1994, Psychometric theory, 3rd edn., McGraw-Hill, New York.

Pooe, R.I.D., Mafini, C. \& Louwry-Okoumba, V.W., 2015, 'The impact of information sharing on supply chain performance under asymmetric information', Journal of Transport and Supply Chain Management 9(1), 1-11.

Prajogo, D. \& Olhager, J., 2012, 'Supply chain integration and performance: The effects of long-term relationships, information technology and sharing, and logistics integration,' International Journal of Production Economics, 135(1) 514-522.

Rashed, C.A.A., Azeem, A. \& Halim, Z., 2010, 'Effect of information and knowledge sharing on supply chain performance: A survey based approach', Journal of Supply Chain Management 3(2), 61-76. https://doi.org/10.12660/joscmv3n2p61-77

Reisinger, Y. \& Mavondo, F. 2005. 'Travel anxiety and intentions to travel internationally: Implications of travel risk perception', Journal of Travel Research, 43, 212-225.

Rosenzweig, E.D., 2009, 'A contingent view of e-collaboration and performance in manufacturing', Journal of Operations Management 27, 462-478. https://doi. org/10.1016/j.jom.2009.03.001
Rossouw, C. \& Binnekade, N., 2013, 'Investigation into the strategic role and effective functioning of the supply chain function in South African organisations', paper read at the SAPICS 35th Annual conference and exhibition, Sun City, South Africa, read at the

Roussel, J.S., 2013, 'The strategic supply chain advantage: Treating supply chain as a strategic asset', paper read at the SAPICS 35th Annual conference and exhibition, Sun City, South Africa, 2-4 June.

Samadi, E. \& Kassou, I., 2015, 'The relationship between IT and supply chain performance: A systematic review and future research', American Journal of Industrial and Business Management 6, 480-495. https://doi.org/10.4236/ ajibm.2016.64044

Sandberg, E., 2007, 'Logistics collaboration in supply chains: Practice vs theory', International Journal of Logistics Management 18(2), 274-293. https://doi. org/10.1108/09574090710816977

Sekaran, U. \& Bougie, R., 2009, Research methods for business: A skill building approach, 5th edn., John Wiley, New York.

Sezen, B., 2008, 'Relative effects of design, integration and information sharing on supply chain performance', Supply Chain Management: An International Journal 13(3), 233-240. https://doi.org/10.1108/13598540810871271

Sheu, C., Yen, H.R. \& Chae, B., 2006, 'Determinants of supplier-retailer collaboration: Evidence from an international study', International Journal of Operations and Production Management 26(1),24-49. https://doi.org/10.1108/01443570610637003

Shou, Z., Yang, L., Zhang, Q. \& Su, C., 2013, 'Market munificence and inter-firm information sharing: The moderating effect of specific assets', Journal of Business Research 66(10), 1-9. https://doi.org/10.1016/j.jbusres.2013.02.039

Shukla, R.K., Garg, D. \& Agarwal, A., 2011, 'Understanding of supply chain: A literature review', International Journal of Engineering Science and Technology 3(3), 20602077.

Sodhi, M.S., Son, B.G. \& Tang, C.S., 2012, 'Perspectives on supply chain risk management', International Journal of Production and Operations Management 21(1), 1-13.

Sukati, I., Hamid, A.B.A., Baharun, R., Tat, H.H. \& Said, F., 2011, 'An investigation of the relationship between supply chain management practices and competitive advantage of the firm', Contemporary Marketing Review 1(4), 1-13.

Taghipour, M., Bagheri, M., Khodarezaei, M. \& Farid, F., 2015, 'Supply chain performance evaluation in the IT industry', International Journal of Research and performance evaluation in the IT industry',
Reviews in Applied Sciences 23(2), 144-156.

Van der Vaat, T. \& Van Donk, D.P., 2008, 'A critical review of survey-based research in supply chain integration', International Journal of Production Economics 111(1), 42-55. https://doi.org/10.1016/j.ijpe.2006.10.011

Vermeulen, Y., Niemann, W. \& Kotzé, T., 2016, 'Supply chain integration: A qualitative exploration of perspectives from plastic manufacturers in Gauteng', Journal of Transport and Supply Chain Management 10(1). https://doi.org/10.4102/jtscm. v10i1.223

Verwaal, E. \& Hesselmans, M., 2004, 'Drivers of supply network governance: An explorative study of the Dutch chemical industry', European Management Journa 22(4), 442-451. https://doi.org/10.1016/j.emj.2004.06.008

Wagner, S.M. \& Bode, C., 2008, 'An empirical examination of supply chain performance along several dimensions of risk', Journal of Business Logistics 29(1), 307-325. https://doi.org/10.1002/j.2158-1592.2008.tb00081.x

Wong, J., 2011, 'A relational view of resources-based theory: The case of internationalization of Li \& Fung Group', Journal of Human Resource and Adult Learning $7(2), 34-39$.

Zhou, H. \& Benton, W.C., 2007, 'Supply chain practice and information sharing', Journal of Operations Management 25(6), 1348-1365. https://doi.org/10.1016/j. jom.2007.01.009 